\title{
METODE REKRUTMEN KARYAWAN MENGGUNAKAN PENDEKATAN UJI CATEGORICAL
}

\author{
${ }^{1}$ Achmad Muchayan, ${ }^{2}$ Firman Aditya, ${ }^{3}$ I Putu Artaya \\ 1'2Fakultas Ekonomi dan Bisnis, Universitas Narotama Surabaya \\ Mail: 1'achmad.muchayan@narotama.ac.id, ${ }^{2}$ firman.aditya@narotama.ac.id, \\ ${ }^{3}$ putu.artaya@narotama.ac.id
}

\begin{abstract}
Bagi pengusaha proses seleksi pegawai merupakan kegiatan penting dalam upaya mendapatkan tenaga kerja atau tenaga kerja yang memadai dalam menerima penugasan untuk melakukan jenis pekerjaan tertentu. Banyak metode yang dapat digunakan dalam proses seleksi karyawan, salah satunya adalah metode analisis kategoris. Apapun jenis metode seleksinya, tentunya perusahaan mengharapkan hasil seleksi yang akurat. Dalam penulisan artikel ini peneliti ingin menunjukkan salah satu bentuk penerapan metode tersebut agar hasil seleksi dapat memberikan gambaran hasil yang transparan. Metode ini bersifat numerik dengan menggunakan pendekatan skor melalui proses focus group discussion.
\end{abstract}

Kata Kunci: Pengukuran performance, seleksi karyawan, uji kategorikal.

\section{PENDAHULUAN}

\section{Latar Belakang Penelitian}

Dalam sebuah perusahaan, baik perusahaan besar atau kecil, kontribusi terbesar dalam menggerakkan perusahaan tersebut adalah sumber daya manusia. Selain faktor sumber daya manusia, masih ada faktor lain yang menjadi pertimbangan yaitu modal, ketrampilan dan pengetahuan. Namun faktor sumber daya manusia merupakan faktor yang dominan peranannya, dibanding faktor lainnya. Dalam sebuah kegiatan ekonomi, perusahaan merupakan suatu usaha yang berkesinambungan dan memiliki tujuan. Untuk mencapai tujuan tersebut, banyak faktor yang harus dipertimbangkan untuk dipergunakan secara kombinasi. Salah satu faktor utama adalah manusia yang mempunyai kualitas yang handal. Dalam perusahaan, peranan sumber daya manusia menjadi faktor penentu keberhasilan sebuah proses kerja, walaupun perannya dapat digantikan oleh robot, mesin, komputer atau peralatan lainnya. Karena peran sumber daya manusia begitu penting maka setiap perusahaan tentunya akan membuat kebijakan untuk dapat mengatasi setiap persoalan yang muncul terkait dengan permasalahan yang dapat menghambat proses atau pencapaian tujuan (Nambudiri, 2010).

Satu permasalahan perusahaan yang perlu mendapat sebuah pemikiran khusus yakni masalah seleksi karyawan yang nantinya ditugaskan untuk mengemban suatu pekerjaan. Umumnya yang menjadi fokus perusahaan adalah kualitas sumber daya manusianya dan metode seleksinya. Merekrut karyawan harus dilakukan secara akurat, dan dilakukan serta direncanakan dengan sebaik-baiknya agar sumber daya manusia yang didapat kelak mampu menghasilkan manfaat yang optimal bagi perusahaan. Disisi lain ketersediaan sumber daya manusia seperti yang diinginkan perusahaan jumlahnya terbatas, oleh karena itu penerapan sebuah metode seleksi merupakan faktor krusial bagi kehidupan jangka panjang perusahaan.

\section{TINJAUAN PUSTAKA}

\section{Sumber Rekruitmen}

Untuk mencukupi kebutuhan perusahaan terhadap tenaga kerja yang memadai keahliannya, perusahaan dapat memperhitungkan dan memikirkan dari mana sumber tenaga kerja dapat dipenuhi. Pertimbangan yang perlu dilakukan oleh perusahaan adalah: 
1. Dalam kegiatan rekruitmen, mengutamakan tenaga kerja dari internal perusahaan atau tenaga kerja dari eksternal?

2. Bagaimana tingkat spesialisasi tenaga kerja yang dibutuhkan?

3. Apakah diperlukan sebuah loyalitas pada diri tenaga kerja yang akan direkrut?

4. Apakah perusahaan menerapkan faktor senioritas dalam rekruitmen?

5. Apakah perlu dipertimbangkan pengembangan karyawan setelah proses rekruitmen selesai dilakukan?

Disamping segenap pertimbangan di atas, perusahaan perlu juga memikirkan dan membuat standar kompensasi tenaga kerja dan jumlah kebutuhan tenaga kerja serta selanjutnya dilakukan tindakan nyata untuk memperoleh tenaga kerja tersebut.

Menurut Nitisemito (2015) untuk memperoleh tenaga kerja yang tepat dapat dilakukan dengan cara sebagai berikut:

"Apabila perusahaan tidak dapat memperoleh personalia yang tepat, maka pekerjaan akan menjadi kurang beres, pemborosan bahan baku, pekerjaan menjadi lambat, banyak kerusakan dan hasil yang tidak memuaskan serta masih banyak lagi akibat yang lain dapat terjadi dan sangat merugikan perusahaan yang bersangkutan"

Bertolak dari pernyataan di atas, maka masalah rekruitmen tidak dapat diabaikan oleh perusahaan, lebih lanjut menurut Winardi (2007), calon tenaga kerja yang akan dipilih berasal dari dua sumber, yaitu:

"Sumber dari dalam perusahaan dan sumber dari luar perusahaan, selama sumber tersebut dapat memenuhi kebutuhan perusahaan dalam pencapaian tujuannya"

\section{Sumber Rekruitmen: Internal}

Sumber tenaga kerja dari dalam perusahaan adalah sumber terbaik karena tenaga kerja dari dalam perusahaan lebih terlatih, khususnya mengenai pemahaman kondisi atau keadaan perusahaan. Tenaga kerja yang bersumber dari dalam perusahaan akan lebih bermanfaat bagi perusahaan untuk memenuhi suatu kebutuhan apabila perusahaan memiliki data lengkap mengenai keahlian, pengalaman, evaluasi, penilaian prestasi tenaga kerja dalam bidangnya, sehingga bila ada lowongan atau kesempatan kerja yang kosong diperusahaan maka dapat dijadikan pertimbangan khusus bagi perusahaan guna pengambilan keputusan serta pemilihan tenaga kerja yang dapat disertai penugasan atau penempatan guna mengisi lowongan tersebut. Keuntungan merekrut tenaga kerja dari dalam perusahaan adalah mampu menciptakan kepuasan kerja, menghindari konflik, penghargaan terhadap prestasi kerja, mampu meningkatkan motivasi, perbaikan loyalitas karyawan dan karyawan sudah mengenal budaya kerja dengan baik diperusahaan (Hasibuan, 2014).

\section{Sumber Rekruitmen: Eksternal}

Sumber eksternal dapat dipertimbangkan apabila ketersediaan tenaga kerja di internal perusahaan tidak mencukupi atau sangat terbatas untuk menempati bidang tertentu, sehingga alternatif rekruitmen tenaga kerja dari eksternal menjadi pertimbangan yang wajar dan dinamis. Tujuannya adalah untuk menyesuaikan job specification. Menurut Winardi (2007), sumber tenaga kerja yang berasal dari luar perusahaan, dapat diperoleh melalui sumbersumber sebagai berikut:

1. Tenaga kerja teman karyawan perusahaan,

2. Kelompok advertensi,

3. Lembaga pendidikan atau pelatihan,

4. Agen tenaga kerja,

5. Daftar tunggu pelamar,

6. Pelamar yang datang langsung. 


\section{Penilaian Program Rekruitmen Karyawan}

Tujuan penilaian merupakan sebuah ukuran apakah program dapat dikatakan berhasil atau tidak. Berhasil tidaknya suatu program rekruitmen dapat diukur dengan beberapa kriteria sebagai berikut (Martoyo, 2015):

1. Banyaknya pelamar,

2. Banyaknya pemilihan karyawan,

3. Banyaknya penempatan karyawan yang berhasil.

Meskipun hal ini merupakan petunjuk yang nearik atau tidak, suatu program rekruitmen karyawan, ketentuan di atas tersebut belum dapat menjamin suksesnya program tersebut. Namun banyaknya penempatan karyawan yang berhasil dalam bidangnya yang sesuai dengan kemampuan, keahlian, pengetahuan, bakat, pendidikan, kesehatan, kondisi fisik, dan sebagainya dapat dirasakan sebagai suatu ukuran yang mampu mendeteksi sebuah prestasi karyawan yang berhasil direkrut oleh perusahaan. Hal ini tentu akan memotivasi karyawan untuk bekerja lebih baik dan bersungguh-sungguh.

\section{Pertimbangan Atribut Dalam Rekruitmen}

Setelah perusahaan dapat menetapkan analisa jabatan, maka dapat ditentukan atribut dan variabel apa saja yang harus dipenuhi oleh calon karyawan agar dapat terpilih dan diterima bekerja di perusahaan. Selanjutnya perusahaan akan memanggil dan melakukan seleksi calon karyawan dari sumber tenaga kerja yang ada. Calon tenaga kerja yang berhasil diterima harus sesuai dan dapat menyesuaikan dengan pekerjaan khusus yang diberikan kepadanya.

Dalam melakukan seleksi (Umar, 2002) ada beberapa atribut yang perlu dipertimbangkan, antara lain sebagai berikut:

1. Keahlian, untuk menjalankan tugas, diperlukan keahlian yang sesuai dengan bidangnya, tujuannya adalah kelancaran dalam proses pelaksanaan pekerjaan.

2. Usia karyawan, kategori usia dalam pelaksanaan pekerjaan di perusahaan dirasakan sangat penting bagi perusahaan, hal ini untuk menjaga kontinyuitas dan produktivitas karyawan yang bersangkutan dalam jangka panjang sampai batas kemampuan karyawan.

3. Jenis kelamin, untuk tugas yang bersifat spesifik, pemilihan karyawan berdasar jenis kelamin, bisa karena faktor atau pertimbangan tertentu, beban pekerjaan tertentu, ketelitian tertentu yang terkandung dalam pekerjaan itu sendiri.

4. Kondisi fisik, terkadang jenis pekerjaan tertentu sangat membutuhkan kekuatan fisik yang prima dan belum tentu semua karyawan mampu diserahi tugas untuk melaksanakan jenis pekerjaan tertentu tersebut.

5. Pengalaman, menerima karyawan dengan pengalaman kerja tertentu, akan terasa banyak manfaatnya, dan pekerjaan yang dibebankan akan langsung dapat dikerjakan tanpa hambatan yang berarti.

6. Pendidikan, persyaratan pendidikan akan lebih banyak berorientasi ke masa depan dalam hal pengembangan perusahaan, penempatan karyawan, promosi jabatan atau karir yang berhubungan dengan pekerjaannya.

7. Kesehatan, pada proses seleksi karyawan, faktor kesehatan tenaga kerja menjadi sesuatu yang penting sebab dengan kesehatan yang dimiliki maka karyawan akan dapat melaksanakan kerja dengan baik dan berhubungan dengan produktivitasnya.

8. Kecerdasan emosi, hal ini memerlukan perhatian khusus, terutama dalam keperluan pengukuran dan penilaian terhadap ambisi, motivasi, disiplin, tanggungjawab, loyalitas, dan kemampuan kerja pelamar yang akan ditugaskan menjalankan pekerjaan nanti.

9. Kepribadian, ukuran ini terlihat pada sikap dalam pelaksanaan tugas sehari-hari, berbentuk abstrak, sehingga membutuhkan alat ukur yang bersifat relatif. 
https://journal.univetbantara.ac.id/index.php/jbfe

10. Tingkat sosial, kondisi ini berhubungan dengan internal individu dan bisa memiliki pengaruh tidak langsung terhadap individu dalam pelaksanaan kegiatan tugas dan pekerjaan.

11. Kompensasi, atribut ini memiliki ikuran nyata terutama dalam meningkatkan kesejahteraan karyawan maupun meningkatkan kondisi ekonomi yang terhubung dengan semangat dan kepuasan kerja.

\section{Standart Atribut Rekruitmen}

Untuk menjamin proses seleksi, penilaian dan pengukuran para pelamar dapat dilakukan secara tepat, cepat dan terukur serta hasilnya bisa obyektif maka perusahaan harus dapat membuat batasan ukuran yang presisi agar dapat memenuhi harapan perusahaan. Apabila segala bentuk penilaian dan pengukuran tidak dapat di buat standart dengan baik dapat mengakibatkan kerugian yang tidak kecil bagi perusahaan baik secara materi maupun moril, dan proses rekruitmen dapat tidak berfungsi sesuai harapan. Secara sederhana dapat disajikan konsep rekruitmen seperti gambar di bawah ini:

Gambar 1. Proses rekruitmen dalam sebuah perusahaan

Sumber: Rivai, 2014.

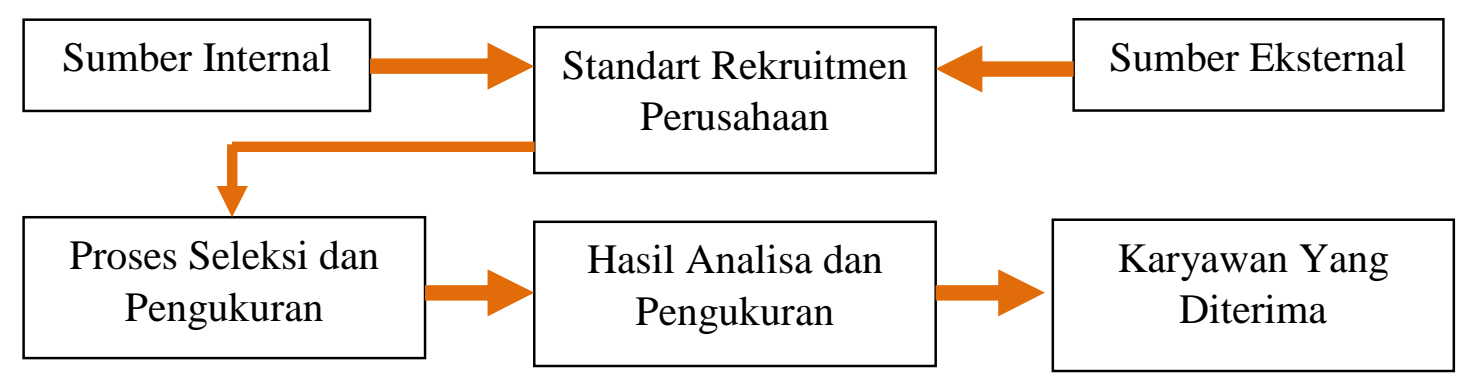

\section{METODE PENELITIAN}

Lokasi Obyek Penelitian

Merupakan salah satu pabrik gula yang terdapat di Candi, tepatnya di jalan raya candi nomor 10 Sidoarjo, pabrik gula yang usianya cukup tua, berdiri sejak tahun 1896 ketika masih di bawah pemerintahan kolonial Belanda. Dan sekarang statusnya menjadi PTP (Perseroan Terbatas Perkebunan) dan masuk wilayah PTP XII-XIII. Operasionalnya di bawah koordinasi PT. Rajawali Nusantara (Persero) dan berkantor di jalan Undaan Kulon Nomor 57-59 Surabaya.

\section{Model Pengukuran Data}

Karena yang di bahas dalam penelitian ini adalah proses rekruitmen karyawan maka model pengukuran data menggunakan data numerik dengan pendekatan data kategori, dengan susunan sebagai berikut (Santoso, 2012):

$1=$ sangat tidak memenuhi; $2=$ tidak memenuhi; $3=$ kurang memenuhi; $4=$ memenuhi; $5=$ sangat memenuhi

\section{Model Analisa Data}

Secara mendasar penerapan uji Categorical sebenarnya untuk menguji atau mendiagnosis sebuah gejala dalam sebuah pengukuran dengan menggunakan skala numerik. Analisa kategori menggunakan data non metrik dan pada kebanyakan kasus data yang digunakan adalah data nominal (kategori). Proses uji sedikit berbeda yaitu menggunakan syntax yaitu serangkaian perintah yang digunakan untuk menjalankan metode tertentu. 
https://journal.univetbantara.ac.id/index.php/jbfe

Dengan menggunakan syntax maka data yang dianalisa langsung bisa dieksekusi (run). Output syntax adalah sebuah grafik berbentuk map (Santoso, 2012).

\section{Sampel Penelitian}

Dalam kasus penelitian ini, yang dijadikan subyek penelitian adalah 7 (tujuh) orang pelamar, yang akan melamar sebagai manajer pada pabrik gula. Setiap pelamar akan di uji menggunakan 11 (sebelas) atribut seleksi yang telah ditetapkan perusahaan yang telah dijelaskan di bagian atas.

\section{PEMBAHASAN}

\section{Penerapan Analisa Kategori}

Pada bagian awal analisa kategori akan ditampilkan hasil nilai 7 (tujuh) pelamar melalui proses diskusi grup tim penilai. Tampilan data adalah sebagai berikut:

Tabel 1. Hasil penilaian diskusi grup tim penilai internal perusahaan

\begin{tabular}{|c|r|c|c|c|c|c|c|c|}
\hline No. & Atribut & P1 & P2 & P3 & P4 & P5 & P6 & P7 \\
\hline 1. & Keahlian & 3 & 4 & 2 & 4 & 4 & 5 & 3 \\
\hline 2. & Usia & 4 & 4 & 5 & 4 & 4 & 5 & 5 \\
\hline 3. & Jenis Kelamin & 5 & 5 & 5 & 5 & 5 & 5 & 5 \\
\hline 4. & Kondisi Fisik & 3 & 4 & 4 & 5 & 5 & 4 & 5 \\
\hline 5. & Pengalaman & 3 & 5 & 5 & 4 & 3 & 3 & 5 \\
\hline 6. & Pendidikan & 5 & 5 & 5 & 5 & 5 & 5 & 5 \\
\hline 7. & Kesehatan & 4 & 5 & 5 & 3 & 4 & 5 & 4 \\
\hline 8. & Kecerdasan Emosi & 5 & 4 & 4 & 5 & 5 & 4 & 4 \\
\hline 9. & Kepribadian & 4 & 4 & 4 & 5 & 5 & 4 & 4 \\
\hline 10. & Tingkat Sosial & 4 & 3 & 2 & 5 & 3 & 3 & 5 \\
\hline 11. & Kompensasi & 3 & 3 & 5 & 4 & 4 & 3 & 5 \\
\hline
\end{tabular}

Sumber: Hasil penilaian tim penilai perusahaan., $\mathrm{P}=$ pelamar.

Hasil penilaian dari grup tim penilai di atas, selanjutnya akan menjadi input dalam analisa kategori melalui eksekusi syntax, sehingga melalui proses syntax tersebut akan diperoleh hasil dalam bentuk grafik sebagai berikut:

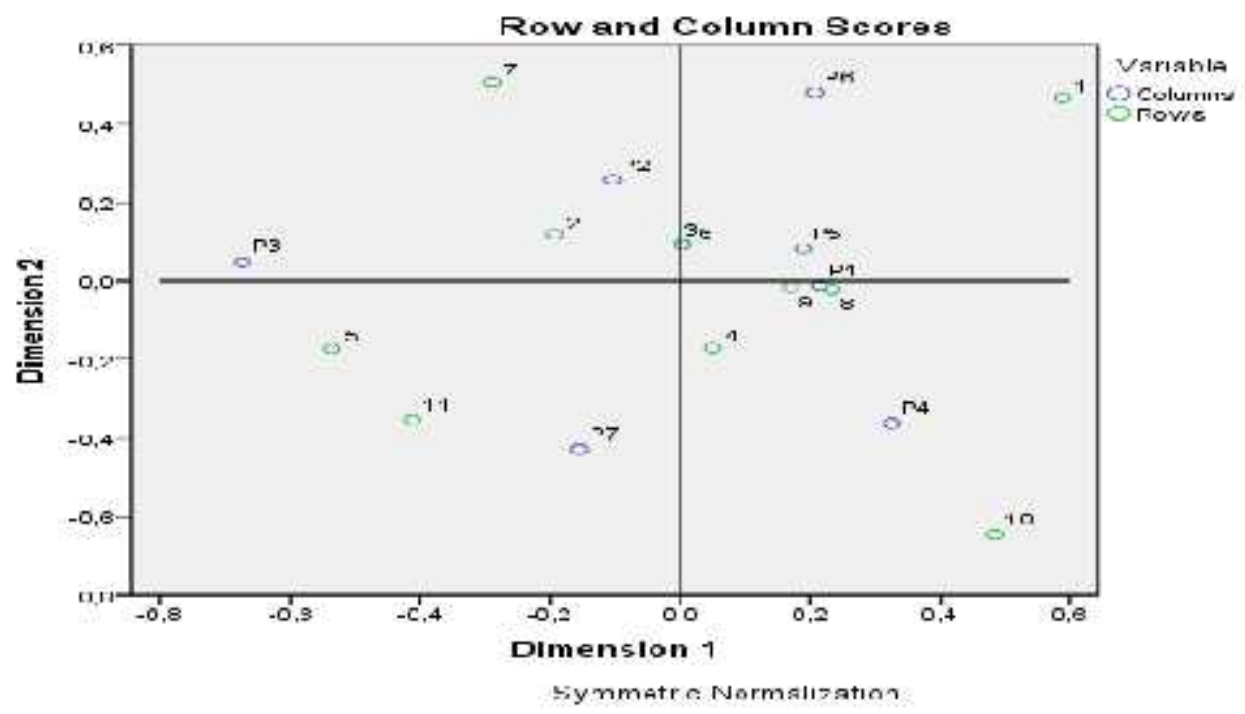

Gambar 1. Hasil pemetaan dalam bentuk kuadran posisi pelamar 
Untuk membahas hasil analisa kategori, grafik yang ditampilkan hanya grafik yang nomor tiga, karena grafik ketiga merupakan tampilan grafik yang paling lengkap, berisi atribut dan posisi 7 (tujuh) pelamar dalam satu tampilan.

Grafik terbagi dalam dua dimensi, yaitu dimensi 1 dan dimensi 2. Dimensi 1 semakin ke kanan nilainya semakin besar dan positif dihitung dati titik sumbu tengah, bergerak ke kanan secara horisontal. Sedang dimensi 2, dihitung dari titik sumbu tengah, semakin ke atas nilainya semakin besar dan positif. Bergerak secara vertikal. Pelamar yang berada di area yang bernilai positif (dimensi 1 dan dimensi2) layak untuk dipertimbangkan untuk diterima dengan ketentuan sebagai berikut:

1. Pelamar yang paling layak diterima adalah pelamar 6 (P6) karena posisinya berada di kuadran 1 yang merupakan perpotongan (arsiran) antara dimensi 1 dan dimensi 2. Jika perusahaan hanya membutuhkan satu karyawan maka hanya pelamar 6 (P6) yang layak diterima.

2. Alternatif pelamar lain yang layak dipertimbangkan untuk diterima adalah pelamar 4 (P4) dan pelamar 2 (P2), karena nilainya positif di setiap dimensi dan posisinya paling dekat dengan pelamar 6 (P6). Jika perusahaan membutuhkan tiga orang karyawan, maka yang layak diterima adalah pelamar 6, pelamar 4, dan pelamar 2 .

3. Jika perusahaan membutuhkan 6 (enam) orang karyawan untuk diterima maka yang layak diterima adalah pelamar 4, pelamar 6, pelamar 2, pelamar 1, pelamar 3, dan pelamar 5. Karena enam pelamar tersebut berada di area yang nilainya positif (baik dimensi1 maupun dimensi 2)

4. Hanya satu orang pelamar yang tidak layak untuk diterima bekerja di perusahaan yaitu pelamar 7, karena pelamar 7 berada di area (kuadran) yang bernilai negatif (baik dimensi 1 dan dimensi2).

Berdasarkan pembahasan tersebut di atas, terlihat dengan jelas bahwa kebijakan perusahaan untuk menerima karyawan ditentukan oleh posisi pelamar pada grafik di atas, dan keputusan dilakukan oleh perusahaan secara fleksibel, yaitu tergantung berapa banyak kebutuhan tenaga kerja atau karyawan yang akan di rekrut melalui proses di atas.

\section{KESIMPULAN DAN REKOMENDASI Kesimpulan}

Jika metode rekruitmen pada perusahaan dilakukan secara obyektif dan bersifat numerik, metode analisa kategori dapat dijadikan alternatif atau pilihan, karena penggunaan atribut dalam proses rekruitmen sangat logis dan mendekati nilai obyektifnya. Artinya hasil yang disajikan dalam grafik dapat dipertanggujawabkan kebenarannya secara signifikan. Sehingga mampu memberikan data dan informasi yang akurat kepada perusahaan dalam hal rekruitmen karyawan dan dapat menjadi pertimbangan tersendiri bagi pihak HRD di internal perusahaan.

\section{Rekomendasi}

Metode ini dapat diterapkan secara obyektif dengan lebih luas untuk keperluan kegiatan rekruitmen pegawai atau karyawan, bila perlu jumlah atribut yang dipergunakan dapat dapat diperbanyak jumlahnya agar proses rekruitmen dapat di nilai berdasarkan obyektifitas yang paling mendekati kebenaran, sehingga dapat mengukur seluruh nilai yang mewakili seorang karyawan baik secara nyata. Dan pada ahirnya nilai yang dihasilkan melalui perhitungan numerik pendekatan metode syntax ini mencakup seluruh keputusan yang berlaku secara wajar pada individu ketika karyawan bekerja secara obyektif pada sebuah perusahaan. 
https://journal.univetbantara.ac.id/index.php/jbfe

\section{DAFTAR PUSTAKA}

Amy R. Overton, Ann C. Lowry, (2013), Conflict Management: Difficult Conversations with Difficult People, Clin Colon Rectal Surg. 2013 Dec; 26(4): 259-264. doi: 10.1055/s0033-1356728.

Barry, Michael, Wilkinson, Adrian. 2015. Pro-social or pro-management? A critique of the conception of employee voice as a pro-social behaviour within organizational behaviour. British Journal of Industrial Relations 54(2): 261-84.

Cottini, Elena, Kato, Takeo, Westergaard-Nielsen, Neils Cristian. 2011. Adverse workplace conditions, high-involvement work practices and labor turnover: Evidence from Danish linked employer-employee data. Labour Economics 18: 872-80.

Cross, D., Burrus, S. W., \& Shaw, M. (2014). Evaluating Conflict between Employees: Exploring the Costs to an Organization. International Journal of Aviation, Aeronautics, and Aerospace, 1(1). https://doi.org/10.15394/ijaaa.2014.1005.

Dohmen, T., Falk, A., Huffman, D., Sunde, U., Schupp, J., \& Wagner, G. G. (2011). Individual risk attitudes: Measurement, determinants, and behavioral consequences. Journal of the European Economic Association, 9(3), 522-550.

Eigen, Zev J., Litwin, Adam Seth. 2014. Justice or just between us? Empirical evidence of the trade-off between procedural and interactional justice in workplace dispute resolution. Industrial and Labor Relations Review 67(1): 171-201.

Hasibuan, Malayu S.P., 2014, Organisasi dan Motivasi: Dasar Peningkatan Produktivitas, Bumi Aksara, Jakarta

Martoyo, Susilo, 2010, Manajemen Sumber Daya Manusia, BPFE, Yogyakarta

Nambudiri, W., Cascio. R., 2010, Managing Human Resources: Productivity, Quality of Work Life, Profits, McGraw Hill, Higher Education, New Jersey.

Nitisemito, Alex, 2015, Manajemen Personalia, Ghalia Indonesia, Jakarta

Pribadiyono, 2002, Mengembangkan Kompetensi Individu Dan Daya Saing Organisasi Di Indonesia, Konferensi I APIO, Surabaya.

Rivai, Veithzal, 2014, Manajemen Sumber Daya Manusia Untuk Perusahaan: Dari Teori Ke Praktisi, Rajawali Press, Jakarta

Santoso, Singgih, 2012, Mengukur Sikap dan Kepuasan Konsumen, Penerbit: PT. Elex Media Komputindo, Jakarta

Umar, Husein, 2002, Evaluasi Kinerja Perusahaan, Gramedia Pustaka Utama, Jakarta

Winardi, 2007, Manajemen Perilaku Organisasi, Prenada Media, Jakarta. 